\title{
Exploring student's pattern generalization strategy in solving prism sticker problem
}

\author{
Lisanul Uswah Sadieda, Siti Lailiyah, Kusaeri, Wachidatul Adaniyah ${ }^{1}$
}

\begin{abstract}
Abstrak: Penelitian ini bertujuan untuk mendeskripsikan tahap-tahap yang dilalui siswa SMP dalam mengembangkan generalisasi pola saat menyelesaikan prism sticker problem dan menentukan jenis strategi yang digunakan. Prism sticker problem merupakan suatu tugas hasil modifikasi dari cube sticker problem yang telah digunakan Lannin (2003) dalam mengembangkan generalisasi pola siswa. Prism sticker problem menggunakan media berbentuk prisma segitiga yang akan ditempeli stiker warna. Subjek dalam penelitian ini adalah siswa kelas 8 SMPN 2 Krian. Hasil penelitian ini menunjukkan bahwa subjek mampu melalui keempat tahap proses generalisasi pola yaitu pemodelan langsung, identifikasi pola, pembuktian pola dan penentuan aturan untuk kasus yang lebih umum. Subjek mampu merumuskan pola ke-n dengan menggunakan simbol aljabar dan menjelaskannya secara verbal. Dalam penelitian ini, subjek cenderung menggunakan strategi counting dan explicit dalam menyelesaikan prism sticker problem.
\end{abstract}

Kata Kunci: Pola generalisasi, Strategi, Prism sticker, Pemecahan masalah

\begin{abstract}
This research aimed to describe the stages through which eighth-grade students develop pattern generalizations when solving prism sticker problem and determine the type of strategy used. Prism sticker problem is a modified task from cube sticker problem that Lannin (2003) has used in developing student's pattern generalization. Prism Sticker problem uses triangular prismshaped media that will be affixed with color stickers. The subjects of the research were eighthgrade students of public junior high schools in Krian City, East Java, Indonesia. The results of this research show that the subjects can go through the four stages of the pattern generalization process, i.e., direct modeling, pattern identification, proof testing of the pattern, and determining the rule for a general case. The subjects can formulate the $\mathrm{n}^{\text {th }}$ pattern by using algebraic symbols and explain it verbally. The results indicate that the subjects tend to use counting and explicit strategies to solve prism sticker problem.
\end{abstract}

Keywords: Pattern generalization, Strategy, Prism sticker problem, Problem-solving

\section{A. Introduction}

Patterns have been widely studied in mathematics (Resnik, 2005; Tikerar, 2009). Almost all mathematical studies are based on patterns and structures. Pattern analysis, descriptions of order and their characteristics are among the goals of mathematics (Vogel, 2005). Patterns in mathematics are closely related to numerical and spatial skills or logical relationships (Mulligan \& Mitchelmore, 2009). Therefore, patterns are commonly found in the studies of algebra, geometry, or mathematical logic. Regarding the association of pattern with algebraic studies, some researchers (Zazkis \& Liljedahl, 2002) see the pattern as a way of approaching algebra because it is a fundamental step to build generalizations, which is the essence of mathematics.

\footnotetext{
${ }^{1}$ Departement of Mathematics Education, State Islamic University Sunan Ampel Surabaya, Jl. A. Yani No.117, Surabaya, Indonesia, lisanuluswah@uinsby.ac.id
} 
Generalization is a means of thinking and communicating. From a mathematical point of view, generalization is a process of looking for a broader pattern. Mason, Burton, and Stacey (2010) state that generalization is a process of looking for patterns and relationships more widely and of making connections in various levels of mathematical thinking. Generalization of patterns in this study is a process of reasoning that departs from a pattern to the general form.

Dindyal (2007) classifies the process of pattern generalization into four stages including (1) direct modeling, (2) pattern identification, (3) proof testing of the pattern, and (4) determining the rule for a general case. The direct modeling is characterized by student activities in determining specific terms by drawing or counting. The direct modeling stage allows the systematic calculation of a particular term. The second stage is pattern identification; that is identifying specific patterns depending on systematic calculations in the first stage. At this stage, students will observe the interrelationships between particular terms, such as observing the difference in patterns on the 2 nd and third and fourth terms. The third stage is pattern testing in which students test their prediction on certain terms that are considered too large, not effective and difficult to do through direct modeling or direct calculation. In the final stages, students state a pattern they have identified in the form of a symbolic statement or a general form algebraically. The four stages of the generalization process described above; however, may not be seen all completely in student activities. Some students may only perform the first stage or direct modeling. Some other students may go up to the third stage of pattern testing while others may not possibly be able to state the patterns into mathematical statements or algebraic symbols. There is also a possibility that some students may be able to state generalizations verbally but cannot formulate the generalizations through symbols.

Although pattern exists in almost all mathematical studies, in fact, most students still have difficulty in solving pattern generalization problems. It can be seen from the research conducted by Marion and Somakim (2005). The results of this study show that only four to six out of 32 students can understand the pattern of numbers based on student strategies in solving the problem of number pattern. There is even a tendency among students to memorize the formula in the book. Similar research conducted by Sari, Subanji and Hidayanto (2016) shows that the difficulties experienced by students in solving the problem of number pattern include (1) determining the pattern and structure to detect regularity, (2) formulating the generalization of the assumption about the observed regularity, (3) evaluating prediction and (4) constructing and evaluating mathematical arguments.

Several experts (Lannin, 2005; Rivera \& Becker, 2008; Stacey, 1989) have also studied problems in pattern generalization. Lannin's research on grade 6 students indicates that students have difficulty in solving tasks that require reasoning patterns, development, and justification. Some students are more focused on specific values than on developing relationships when they make a generalization. The results of Rivera \& Becker's study show that the numerical strategy used by students to develop algebraic generalizations is good, but the students are less able to represent common rules found visually. The results of Stacey's study show that many students still use direct comparison methods that are less suitable for making generalizations. International institutions also research the problem of pattern generalization. The results of the 2003 TIMSS research on Indonesian students show that the number of learners who can correctly answer the problem of pattern generalization is $7 \%$ below the international standard average (Mullis, Martin, Michael, \& Arora, 2003). The results 
of the 2007 TIMSS research on students in Singapore show that when given problem in the form of 4 rows of rectangles formed from 13 matchsticks, students in the majority cannot relate the number of squares formed and the number of matchsticks required (Mullis, Martin, Michael, \& Arora, 2007).

Some researchers have conducted studies using numerical situation, such as Ladders problem (Stacey, 1989), The Shaded Squares problem (Steele \& Johanning, 2004) and Cube Sticker problem (Lannin, 2003), to develop students' algebraic reasoning through generalization. This study will use problems modified from Cube Sticker problem that has been used by Lannin (2003) because it uses interesting media for the student. Besides that, based on the result of Lannin's research, Cube Sticker problem provide opportunities for the students to use more than one generalization strategy. It allows students to build generalizations by associating arithmetic calculations and geometry.

Cube Stickers problem is a task that asks the student to determine the number of stickers needed to cover the surface of the building that composed of several cubes. It uses colored cube-shaped media. The cubes can be arranged horizontally or vertically in such a way as to form a new form of block arrangement (Lannin, 2003). Cube Sticker problem has two characteristics in helping students generalize the pattern. First, the problem requires students to find the number of sticker blocks of different lengths before asking students to formulate the general rules. Second, the problem encourages students to use picture and calculation strategies to formulate generalizations. It makes students use numerical and visual calculation strategies in identifying the relationship between arithmetic and geometry to formulate generalizations.

Drawing from Lannin (2003) on giving Cube Sticker problem to develop students' algebraic reasoning through generalization, the current research developed Prism Sticker problem to assist students in pattern generalization. So, the difference between this research and Lannin's research lies in the task used. Prism Sticker problem is a modified task from Cube Sticker problem. Modifications were made to the media used and the questions asked. Prism Sticker problem uses triangular prism-shaped media that will be affixed with color stickers. Students were asked to arrange any patterns from the prisms presented. Furthermore, students were asked to determine the number of stickers required to stick to all sides of the newly formed prism arrangement. Through these activities, students were encouraged to identify patterns to formulate general rules of the pattern of problems presented.

Prism Sticker problem has two characteristics similar to Cube Sticker problem; those are encouraging students to develop the general rules and assisting students to identify the arithmetical relationship and the geometrical form based on the context. In addition to these two advantages, Prism Sticker problem has an additional benefit compared to Cube Sticker problem. In contrast to cubes which only have a square side, the triangular prism has triangular and rectangular sides. Therefore, the use of triangular prisms will enable students to arrange any patterns in such a new way that various new forms can be arranged. Differences in the arrangements encourage students to use various strategies to formulate general rules of a pattern. Thus, students have the opportunity to use more than one strategy to generalize the pattern. These various strategies will encourage students to formulate general rules of different patterns. In other words, Prism Sticker problem theoretically can be used as alternative learning media to help students generalize pattern because it can encourage different strategies and rule formulation of different patterns.

Several strategies can be used to solve the generalizing problem, such as Cube Sticker problem. Barbosa, Vale, and Palhares (2009) classify pattern generalization strategies into five 
groups covering counting, whole-object, difference, explicit, and guess and check strategies. In counting strategy, students will draw the problems presented and do the calculations directly. The whole-object strategy is a strategy in which students use one part as a unit to build a larger unit using multiples the unit. While difference strategy is a strategy that uses a common difference as a multiplying factor. In an explicit strategy, students can discover a rule based on the context of the problem. The last strategy is guess and check, students will guess a rule by trying multiple input values to check its validity.

The use of Prism Sticker problem as alternative learning media to help students generalize pattern indeed still requires empirical evidence including to find out whether prism sticker problems encourage students to go through the stages of the pattern generalization process as described by Dindyal (2007). Based on this reasoning, the purpose of this research is to describe the stages through which 8th-grade students develop pattern generalizations when solving Prism Sticker problem and determine the type of strategy used.

\section{B. Methods}

This research is a case study conducted in a public secondary school in Krian City, East Java, Indonesia. The subjects of this study were two high-achiever students. The subjects were coded as S1 and S2. The reason for choosing the high-achiever students because they have a higher possibility to use various strategies in pattern generalization. So that the researchers can get an idea of how far the Prisms Sticker problem can develop student pattern generalization strategies.

The data collection started by having document study of students' reports on 7th grade and first semester of 8th grade. This document study was to select two high-achiever students. Both selected subjects were then given pattern generalization tests using Prism Sticker problem (see figure 1). Subsequently, after the test, interviews were conducted based on written test results of both subjects.

You have some triangular prisms and you need to arrange them to build some new forms. Stick every side of the new forms with a colored sticker that has the corresponding shape. Follow the steps below.

1. Take one prism and stick its every side with the sticker provided. How many stickers do you need to cover all the sides of the prism? Elaborate your answer!

2. Take two prisms and arrange them to form a new prism. How many stickers do you need to cover all the sides of the new prism? Explain!

3. Take three prisms and arrange them to form a new prism. How many stickers do you need to cover all the sides of the new prism? Elaborate your answer!

4. If you take 27 prisms and arrange them to make a new prism, how many stickers do you have to cover all the sides of the new prism? Explain!

5. If you take 50 prisms and arrange them to form a new prism, how many stickers do you need to cover all the sides of the new prism? Explain!

6. If you take $n$ prisms and arrange them to form a new prism, how many stickers do you need to cover all the sides of the new prism? Elaborate your answer!

Figure 1. Prism Sticker Problem 
The data analysis was conducted by reviewing the results of the written test and the responses from the interview. The points of analysis include the strategy used by the subjects, how the subjects formulate the general rules of the pattern of the problems presented, and the reasons for the use of the rules. The conclusions related to the stages that students go through in solving Prism Sticker problem are based on Dindyal theory (2007) while the strategies used by students were analyzed by a generalization strategies framework compiled by Barbosa et al. (2009) as seen in the following table.

Table 1. Generalization strategies framework

\begin{tabular}{|c|c|c|}
\hline \multicolumn{2}{|c|}{ Strategy } & $\begin{array}{c}\text { Description } \\
\end{array}$ \\
\hline Counting & & $\begin{array}{l}\text { When determining specific terms, students will draw the problems } \\
\text { presented and do the calculations directly. An example of a } \\
\text { research result on Cube Stickers problem may be that a student } \\
\text { using counting strategy makes a statement "we can determine the } \\
\text { number of stickers needed by first arranging blocks, then, } \\
\text { counting the number of the sides". This statement explains that the } \\
\text { student's strategy begins by arranging the blocks and counts the } \\
\text { number of stickers later. }\end{array}$ \\
\hline \multirow[t]{3}{*}{$\begin{array}{l}\text { Whole- } \\
\text { object }\end{array}$} & $\begin{array}{l}\text { Whole object- } \\
\text { no adjustment }\end{array}$ & $\begin{array}{l}\text { The students perceive a particular term as a part and use one part } \\
\text { as a unit to build a larger unit by making the unit as the multiplier. } \\
\text { However, students do not make any final adjustments after } \\
\text { multiplication. }\end{array}$ \\
\hline & $\begin{array}{l}\text { Whole object- } \\
\text { numeric } \\
\text { adjustment }\end{array}$ & $\begin{array}{l}\text { A strategy involves final adjustments after multiplication. The } \\
\text { adjustments are based on the numerical characteristics of the unit. }\end{array}$ \\
\hline & $\begin{array}{l}\text { Whole object- } \\
\text { visual } \\
\text { adjustment }\end{array}$ & $\begin{array}{l}\text { The students make final adjustments based on the consideration of } \\
\text { the context of the problems presented. The whole object-visual } \\
\text { adjustment strategy allows students to build the general rule of a } \\
\text { pattern. }\end{array}$ \\
\hline \multirow[t]{3}{*}{ Difference } & Recursive & $\begin{array}{l}\text { The students extend the pattern when asked to determine } \\
\text { particular terms to complete a pattern generalization task. Students } \\
\text { using this strategy will first see the typical difference in the known } \\
\text { terms. }\end{array}$ \\
\hline & $\begin{array}{l}\text { Rate no } \\
\text { adjustment }\end{array}$ & $\begin{array}{l}\text { The students use the common difference as multiplication factors } \\
\text { without making final adjustments. Students using this strategy will } \\
\text { see the rate of addition. Then, to determine a particular term, the } \\
\text { students multiply the rate of addition by the desired term. }\end{array}$ \\
\hline & $\begin{array}{l}\text { Rate } \\
\text { adjustment }\end{array}$ & $\begin{array}{l}\text { This strategy is similar to the rate no adjustment strategy. The } \\
\text { difference is that after students multiply the rate of addition to the } \\
\text { desired term, students make final adjustments by looking at the } \\
\text { context of the problem presented. }\end{array}$ \\
\hline Explicit & & $\begin{array}{l}\text { The students will immediately see or look for patterns of problems } \\
\text { presented. The explicit strategy is useful for students to relate the } \\
\text { rules they made themselves to the problem situations being } \\
\text { presented. This strategy allows students to determine the number } \\
\text { of stickers required for blocks of any length. }\end{array}$ \\
\hline
\end{tabular}




\begin{tabular}{ll}
\hline \multicolumn{1}{c}{ Strategy } & \multicolumn{1}{c}{ Description } \\
\hline Guess and check & The students using the guess and check strategy may say "I try to \\
draw a pattern one by one then I multiply 4 and add it with $2 "$. \\
Students using this strategy will make some predictions to get a \\
general rule. Students using this strategy are commonly unable to \\
explain why the rule can apply to any $n$ value.
\end{tabular}

\section{Findings and Discussion}

Both subjects can determine the number of stickers needed to arrange 1,2 and 3 prisms by well. It is reflected in the following excerpt from an interview by one of the researchers (R) and the two subjects ( $\mathrm{S} 1$ and $\mathrm{S} 2$ ).

R: How did you determine the number of stickers needed for the arrangement of 1 prism, 2 prisms, 3 prisms, and the following prisms?

S1: By pasting one prism to the other one at a time, then, [I] pasted the stickers and counted the number of stickers manually.

P: What steps did you take to solve the problem?

S2: Manually

$P: \quad$ Can you explain what do you mean by manually?

S2: By direct practice [application] using the prisms

$P$ : How did you determine the number of stickers needed for 1 prism, 2 prisms or 3 prisms?

S2: First, [I] calculated the number of stickers needed for 1 prism, then the number of the combined 2 prisms and 3 prisms.

The above excerpt shows that both subjects first arranged the prisms, pasted the stickers on every side that did not coincide with other sides and manually calculated the number of stickers needed. This strategy used by the subjects represents the counting strategy for pattern generalization. In spite of the same strategy used, the two subjects have different ways of arranging the prisms. S1 tended to arrange the prisms in a long form like a stem while S2 arrange the prisms by inserting the third prism between the other two prisms. These different ways are reflected in Figure 2 and Figure 3 below.

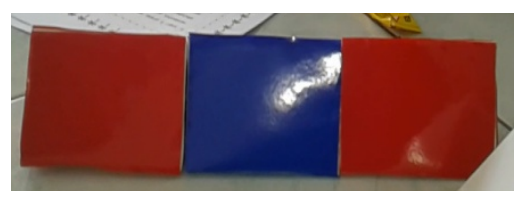

Figure 2. The form of prism arrangement by S1

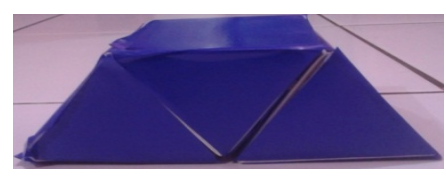

Figure 3. The form of prism arrangement by S2

The different forms produced by the two subjects show that prism stickers problem as a media allows students to construct various arrangement patterns in such a way as to produce different new forms. The difference in the patterns produced by the subjects is because of their different levels of creativity. 
The arrangements as presented in Figures 2 and Figure 3 were used by the subjects as the basis to draw the arrangement pattern of 27 prisms for a problem no. 4 (Figure 2). S1 and S2 have different model pictures for the arrangement of 27 prisms as reflected in Figure 4 and Figure 5 below.

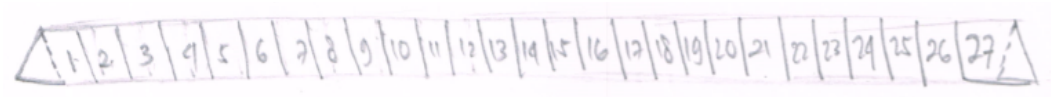

Figure 4. The arrangement of 27 prisms by $\mathrm{S} 1$

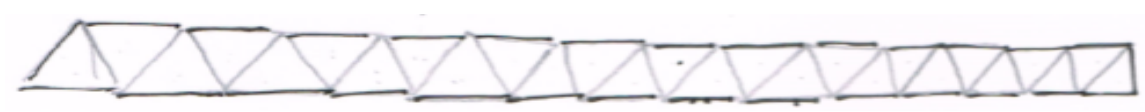

Figure 5. The arrangement of 27 prisms by S2

Both subjects no longer used real objects to determine the number of stickers needed. They instead used their imagination to count the number of stickers needed for 27 prisms arrangement. The excerpt of the interview below reflects S1's strategy used to determine the number of stickers.

$R$ : Well, to determine the $27^{\text {th }}$ prism I see you were using the image. How can you determine the number of stickers needed for the 27 prisms arrangement through the image?

S1: With that picture, [I] can imagine the prisms. So [I] can calculate the number of stickers needed for the arrangement of 27 prisms. Each prism arrangement has different sides from the sides [of the prisms in the arrangement].

$P$ : Can you explain what you meant by 'different' sides?

S1: So, the 27 prisms arrangement has two prisms at each end of the arrangement. The rest are in the middle of the arrangement and each has 3 sides because two of their sides coincide with the sides of the other prism. From here, I categorized the prisms into those having 3 sides and results in 75 stickers. For the two prisms at both ends have 4 sides because only one of their sides coincides with the sides of other prisms. These two categories result in 83 stickers for the arrangement of 27 prisms.

The above excerpt of the interview indicates that S1 determine the number of stickers by grouping the number of prisms sides between those at the end and middle of the arrangement. S1 identified that there were 25 prisms in the middle of the arrangement with each having 2 sides coinciding with other prisms. Therefore, each prism had 3 sides with stickers. Meanwhile, the two prisms at the end of the arrangement each had only 1 coinciding side and thus had four stickers. From this reasoning, the numbers of stickers needed in the arrangement of 27 prisms can be calculated using the formula of $(3 \times 25)+(2 \times 4)=83$. Different from S1, $\mathrm{S} 2$ determined the number of stickers by categorizing the sides of the prisms into triangular and rectangular shapes as can be seen from the following excerpt.

R: I see that to arrange 27 prisms, you use the picture. Can you explain how you determine the number of stickers needed through the picture?

S2: I calculated it, I was thinking, in the picture we can only see the front side, in a triangular shape, the same as the back side. The other sides are rectangular.

$R$ : Okay. So you look at two different sides, the triangular and rectangular sides. Then how do you know the total number of stickers needed for the arrangement of 27 prisms from both sides? 
S2: I used the picture of 27 triangles. Then, both the front and back sides have a triangular shape, so we multiply 27 by 2. Then, we calculate the number of rectangular shapes, also through pictures, both the upper and lower sides. Then, we add 2 sides for each side and add all them up.

R: So, you calculated each shape of the sides then summed them all up to get the total number of stickers?

S2: Yes

S2 calculated the number of stickers needed by adding the number of triangular sides and rectangular sides. Although the picture is drawn only shows one side of the arrangement, S2 can imagine the form of the other sides of the picture based on his earlier activities in arranging 3 prisms. S2 seems to realize that the back side of the picture also has triangular top sides and rectangular bottom and left/right sides. To determine the number of stickers needed on the triangular side, S2 multiplied 27 by 2 . Based on the picture, S2 recognized that the rectangular top and bottom sides are in accordance with the triangular top and bottom sides. Therefore, to determine the number of stickers on the rectangular sides, S2 only needed to add 27 with 2 sides on the left and right. So, the total number of stickers needed for the arrangement of 27 prisms is $(27 \times 2)+27+2=83$ as reflected in the written answer presented in Figure 6 . This strategy of pattern generalization used by S1 and S2 is categorized as a counting strategy.

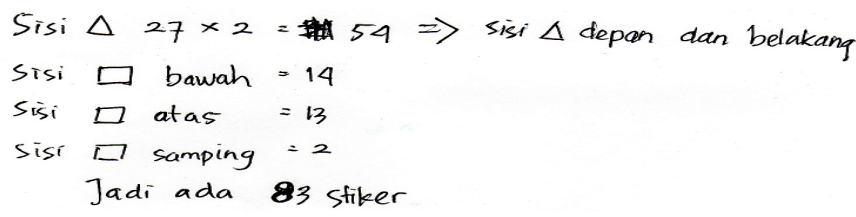

Figure 6. The answer of problem no. 4 written by S2

The above series of activities indicate that both subjects had been through the direct modeling stage and pattern identification stage in solving Prism Sticker problem. It is clear from their activity in the direct counting of the stickers pasted in the prisms and their activity in determining a particular term using a picture of prisms arrangement and in doing calculation systematically to determine the number of stickers needed. Both subjects can also formulate and explain the rules used to determine the number of stickers in a particular arrangement of prism based on the characteristics of the picture representing the arrangement. Although the two subjects applied in different ways, both of them use a counting strategy.

The third stage of pattern generalization process is pattern testing. In this stage, S1 directly used the rule formulated earlier to determine the number of stickers needed for the arrangement of 50 prisms. It is reflected by the answer for a problem no. 5 presented in Figure 7.

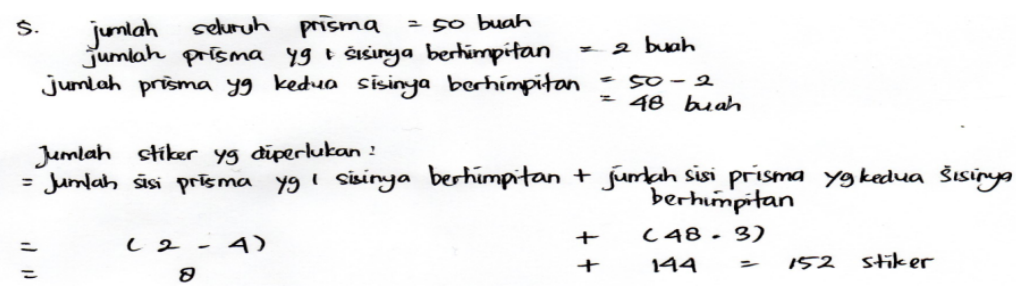

Figure 7. The answer of problem no. 5 by S1 
$\mathrm{S} 1$ began the pattern generalization process by determining the number of prisms in the middle of the arrangement and multiplying it by 3 . S1 then added the number of sides of the prisms at both ends of the arrangement to the result of the multiplication. S1 applied the same steps systematically and consistently to determine the larger terms. The same way was also applied by S2 in which S2 determined the number of stickers for 50 prism-arrangement by determining the number of rectangular and triangular sides and adding them based on the formula identified in the earlier steps. Figure 8 shows the answer of S2.

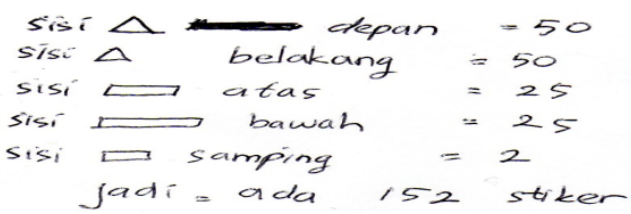

Figure 8. The answer of problem no. 5 by S2

Based on the rule formulated by S2, for 50 prisms there will be 50 triangular sides in each of the front and back parts of the arrangement. Meanwhile, the rectangular sides on the top and bottom sides correspond to those on the triangular sides on the front and back part of the arrangement making the total of 50. Therefore, the number of stickers needed for the arrangement of 50 prisms is $100+50+2=152$.

At this stage, both S1 and S2 used generalization strategy by considering the context of the problem presented. Both subjects searched for regularity of the pattern based on the pattern developed for 2, 3 and 27 prisms. They, then, relate the rule for the pattern of other similar situation presented to them. In other words, they use an explicit strategy.

The final stage of the pattern generalization process is to determine the general rule of a pattern. Both subjects can algebraically formulate and state the pattern they identified. The differences in the prism arrangement and pattern identification influence the process taken by both subjects in constructing the nth term. S1 provides two alternative patterns for the nth term while S2 only has one pattern. Figure 9 shows the answer by S1 for the first alternative pattern.

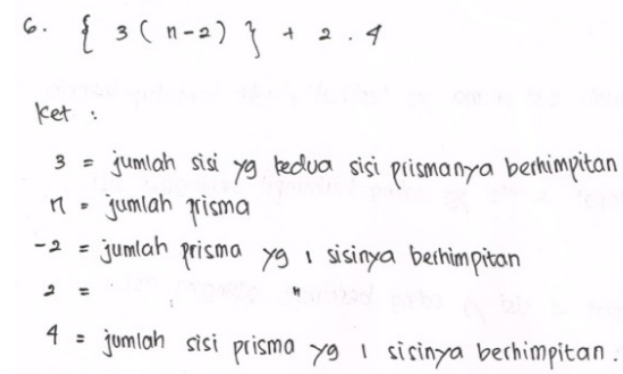

Figure 9. The answer for problem no. 6 by S1

Based on the result of pattern identification in earlier problems, $\mathrm{S} 1$ got the general rule of $(3 \times(n-2))$ for the prisms in the middle of the arrangement. The formula $(3 \times(n-2))$ is drawn from the characteristics of the prisms in the middle of the arrangement as having 3 sides while to determine the number of prisms in the middle. S1 subtracted the number of the total prism (n) by 2 prisms at both ends of the arrangement. For the prisms at both ends, S1 drew the general rule of $2 \times 4$ in which each prism has 4 sides. The first and second rules result in the formula of $(3 \times(n-2))+2 \times 4$. In this case, S1 used explicit strategy. 
S1 can find an alternative way to formulate the nth pattern correctly. This can be shown in the following answer (Figure 10) by S1.

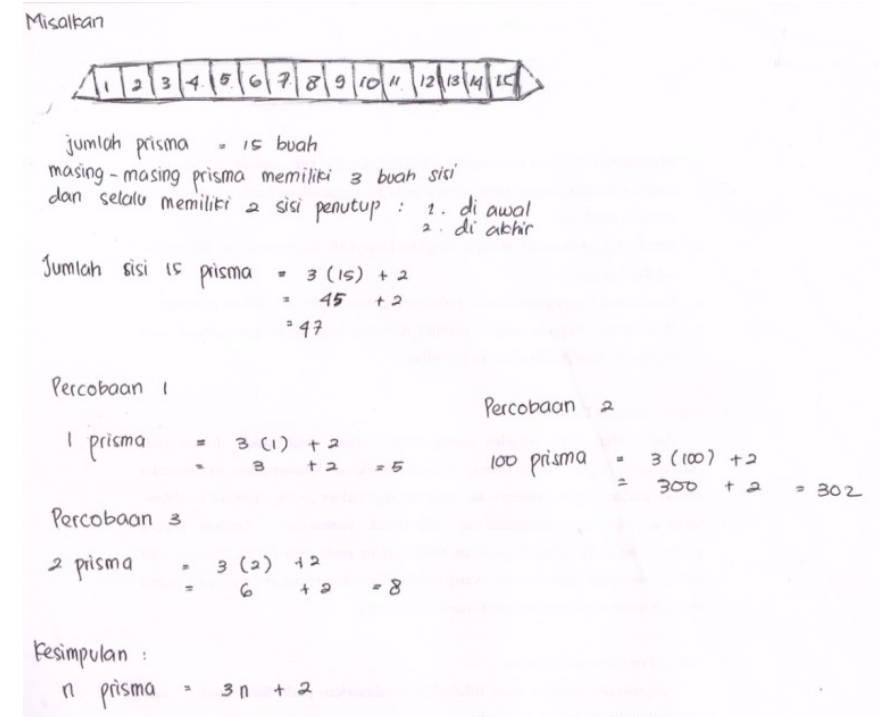

Figure 10. Alternative answer for problem no. 6 by S1

S1 seems to begin the process by direct modeling and pattern identification to solve the problem of 15 prisms arrangement. S1 realized that there is a different pattern for the arrangement of 15 prisms. S1 got the total number of 47 stickers needed for the arrangement of 15 prisms. S1 stated that every prism needs 3 stickers except those at the ends of the arrangement that need an additional 1 sticker each. That is why S1 multiplied 3 by 15 and added 2 other stickers. It is reflected in the $\mathrm{S} 1$ responses below.

S1: Because each of these prisms has 3 sides (the subject pointed the answer) and for the prisms at the beginning and at the end [of the arrangement] have an additional one side each.

R: Why do they have 1 other side?

S1: Because 1 side does not coincide with the other side, while [for the prisms in] the middle of both sides coincides.

The above response shows that $\mathrm{S} 1$ used counting strategy.

S1 then did the pattern testing to determine the number of stickers needed for the arrangement of 1, 2 and 100 prisms as seen in Figure 10. From the above experiments, S1 observed that the regularity of the pattern and concluded that the formula for the pattern of $n$th is $3 n+2$. This shows that $S 1$ used explicit strategy. The above explanation also shows that $S 1$ can formulate the nth pattern using algebraic symbol and verbally explain the rules for the pattern. Nevertheless, it seems that S1 does not realize that the first alternative pattern of $n$th is equivalent to the second alternative pattern. With algebraic calculation, it can be found that (3 $\times(n-2))+2 \times 4=(3 n-6)+8=3 n+2$.

Different from S1, S2 formulated the rules of the pattern based on the result of pattern identification on the previous problem and got the general rule $3 n+2$. This general rule is the same as the second alternative pattern formulated by S1 but the process of formulating the rule for $n^{\text {th }}$ is different as can be presented in Figure 11.

The answer written above shows that S2 used explicit strategy. S2 experimented with an arrangement of 3 prisms. From the experiment, S2 applied the pattern of the 3rd term to 
construct the nth term. S2 saw the triangular front, and back sides of the prisms always have the same number for any $\mathrm{n}$. Meanwhile, the number of stickers needed for the rectangular sides is also $\mathrm{n}$. To calculate the total number of stickers needed, S2 added 1 for each of the rectangular sides at both ends and got the formula of $3 n+2$. It is reflected in the following excerpt from the interview.

$R$ : How can it have $2 n$ here?

S2: Because this side (while pointing at the picture of triangular sides made) is the same as the other side at the back each with some $n$.

$R: \quad$ Fine. Then, it seems that there is an alternative answer to the rectangular sides of $n+2$. Can you explain how did you get $n+2$ ?

S2: We have $n$ number of rectangular sides, while each end of the arrangement has an additional 1 rectangular side, so I add 2.

This shows that $\mathrm{S} 2$ can successfully formulate the $\mathrm{n}^{\text {th }}$ pattern using algebraic symbol and explain the pattern verbally.

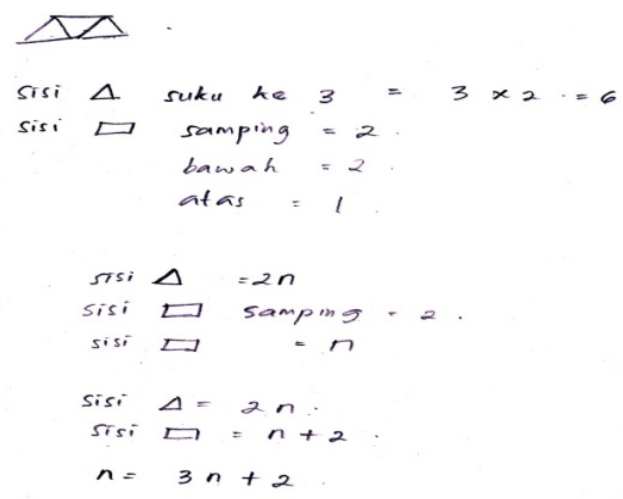

Figure 11. The answer of problem no. 6 by S2

The above explanation shows that the subjects can go through the four stages of pattern generalization and tend to use counting and explicit strategies in solving the Prism Sticker problem. The subject used counting strategy for relatively small terms and tended to use explicit strategies for relatively large terms and the nth term.

The selection of counting and explicit strategies is possibly because the Prism Sticker problem is designed to encourage students to think from concrete to abstract, starting from the use of a real object to the construction of the formula for the nth term. This inductive thinking is allowed in mathematics teaching at a school in order to accommodate the students' intellectual development. The problems presented through inductive thinking will reduce the abstract character of mathematical objects. Therefore, they will be more easily solved by the students.

That is why both subjects of the study tended to model the problem using the picture to get the visual representation (counting strategy). From the pictorial representation, the subject can then identify the characteristics of the prism arrangement and can later imagine the real object when presented with the problem of the larger term. Visual representation enables subject to find the pattern more easily and to apply the pattern in other contexts (explicit strategy) as seen in the results of interview S1 and S2 in solving the question no.4.

This activity trains students to imagine visually concrete objects (visual imagery). In the interview, the two subjects of the research stated that they imagine the three-dimensional 
object when they looked at its two-dimensional picture. It enables them to imagine the back, top, bottom, left and right sides of the arrangement although these sides are not visible in the two-dimensional picture. Prism' characteristics vary depending on the form of the base. The base form determines the variations of the prism's sides. The variations enable varieties of the possible prisms arrangement. It is shown from the different arrangements by the two subjects of the studies. These differences result in different pattern identification which then also stimulate the emergent of various pattern generalization strategies applied by the students.

Besides that, the Prism Sticker problem encourages students to verbally and symbolically make a generalization. It is in line with Swafford and Langrall's (2000) idea in that pattern generalization can be stated algebraically and verbally. While the previous study by Dindyal (2007) found that students avoid verbal generalization and tend to formulate generalization using algebraic symbols only, this study found that Prism Sticker problems number 1 to 5 enable students to explain the pattern generalization verbally. It is because the students were asked to explain, using their language, the rules that they found in the pattern identification process. Problem number 6 trained the students to make pattern generalization using algebraic symbols. The students were trained to determine the numbers that later change into independent variables in the formula for the nth term. The process of finding the independent variables is different from one student to the other. Nevertheless, both subjects can successfully found the variables and find the right formula for the $\mathrm{n}^{\text {th }}$ term.

The result of this research that gives an overview of the ways student work with patterns and developing their strategies may contribute to significant teaching decisions, about the ways to increase algebraic reasoning student through generalization. This research also shows that the use of Prism Sticker problems has proven to be a good alternative way for a teacher to help students develop their generalization strategies. These findings support Lannin $(2003,2005)$ that task factor is one of the factors that influence students' selection on the strategies they use.

\section{Conclusion}

Based on the results of the analysis and discussion, 8th-grade students go through direct modeling stage, pattern identification stage, pattern test, and general rule determination stages in developing pattern generalizations when solving Prism Sticker problem. Subject tend to use counting and explicit strategies to solve Prism Sticker problem. Students perform direct modeling using numerical calculations and images. In the identification stage, students find patterns based on the context of the problems presented. In the pattern testing stage, the students performed a truth check of the identified pattern rules and used the identification results to determine the larger terms. In the final stage, the students can formulate the $\mathrm{n}^{\text {th }}$ pattern by stating it into algebraic symbols and explaining it verbally.

\section{References}

Barbosa, A., Vale, I., \& Palhares, P. (2009). Exploring generalization with the visual pattern: task developed with pre-algebra students. International Meeting on Patterns, (pp. 1-14).

Dindyal, J. (2007). High school students' use of patterns and generalisations. The 30th annual conference of the Mathematics Education Research Group of Australasia (pp. 236-245). MERGA Inc. 
Lannin, J. K. (2003). Developing algebraic reasoning through generalization. Mathematics Teaching in The Middle School, 8(7), 342-348.

Lannin, J. K. (2005). Generalization and justification: The challenge of introducing algebraic reasoning through patterning activities. Mathematical Thinking and Learning, 7(3), 231-258.

Marion, Zulkardi, \& Somakim. (2005). Desain pembelajaran pola bilangan menggunakan model jaring laba-laba di SMP. Jurnal Kependidikan, 45(1), 44-61.

Mason, J., Burton, L., \& Stacey, K. (2010). Thinking mathematically (2nd ed.). Edinburg: Pearson.

Mulligan, J., \& Mitchelmore, M. (2009). Awareness of pattern and structure in early mathematical development. Mathematics Education Research Journal, 21(2), 33-49.

Mullis, I., Martin, O., Michael, P., \& Arora, A. (2003). TIMSS 2003 International results in mathematics. Chestnut Hill, MA: TIMSS \& PIRLS International Study Center.

Mullis, I., Martin, O., Michael, P., \& Arora, A. (2007). TIMSS 2007 International results in mathematics. Chestnul Hill, MA: TIMSS \& PIRLS International Study Center.

Resnik, M. (2005). Mathematics as a science of mathematics. Oxford: University Press.

Rivera, F., \& Becker, J. (2008). Middle school children's cognitive perceptions of constructive and deconstructive generalization involving linear figural patterns. $Z D M, 40(1), 65-82$.

Sari, N., Subanji, \& Hidayanto, E. (2016). Diagnosis kesulitan penalaran matematis siswa dalam menyelesaikan masalah pola bilangan dan pemberian scaffolding. Proceedings of Konferensi Nasional Penelitian Matematika dan Pembelajarannya (KNPMP 1), p. 385-394.

Stacey, K. (1989). Finding and using patterns in linear generalising problems. Educational Studies in Mathematics, 20(2), 147-164.

Steele, D. F., \& Johanning, D. I. (2004). A Schematic-theoretic view of problem solving and development of algebraic thinking. Educational Studies in Mathematics, 57, 65-90.

Swafford, J., \& Langrall, C. (2000). Grade 6 Student's preinstructional use of equations to describe and represent problem situations. Journal in Research Mathematics Education, 31, 89-112.

Tikerar, V. (2009). Deceptive pattern in mathematics. International Journal of Mathematical Science Education, 2(1), 13-21.

Vogel, R. (2005). Pattern: A fundamental idea of mathematical thinking and learning. ZDM, 37(5), 445449.

Zazkis, R., \& Liljedahl, P. (2002). Generalization of patterns: The tension between algebraic thinking and algebraic notation. Educational Studies in Mathematics, 49, 379-402. 